\title{
Carbon stock and mineral factors controlling soil organic carbon in a climatic gradient, Golestan province
}

\author{
M. Zeraatpishe ${ }^{1^{*}}$ and F. Khormali ${ }^{2}$ \\ ${ }^{1}$ Department of Soil Science. Gorgan University of Agricultural Sciences and Natural Resources, Gorgan, Iran. \\ ${ }^{2}$ Department of Soil Science. Gorgan University of Agricultural Sciences and Natural Resources, Gorgan, Iran. \\ *Corresponding author: Zeraatpishem@yahoo.com
}

\begin{abstract}
Organic matter content of the many soils is less than $5 \%$ by weight; nevertheless this small amount of organic matter (OM) has a significant impact on soil properties. A study to evaluate the role of climate in distribution of organic carbon (OC) and mineral factors (such as soil composition, soil stability and clay minerals) controlling OC was performed. Seven surface soils were collected $(0-20 \mathrm{~cm}$ depth) with three replications in a climate gradient (200 to $800 \mathrm{~mm}$ of rainfall). The results showed that aggregates $<0.053 \mathrm{~mm}$ in most of the soils had the lowest organic matter content (Figure 2), and carbon stock increased with increasing in the aggregates size in most soils. There was no significant relationship between OC content and clay mineral content, but there was significant relationship for illite and chlorite. It can therefore be deduced that OC stock is probably controlled mainly by climate factor than clay minerals. Oxalate iron was positively related to OC content, but this relationship does not apply for dithionite iron. The relationship between soil OC content and specific surface area (SSA, $\mathrm{g} \mathrm{m}^{-2}$ ) of the soil was positive and significantly correlated. Labile soil OC content had a positive relationship with the climate index $\left(\mathrm{P} / \mathrm{ET}^{\circ}\right)$. As the index increased the potential loss of OC content increased, as well. Labile OC content was estimated between 0.49 to $16.64 \mathrm{~g} \mathrm{~kg}^{-1}$ and a potential loss of OC was between 1.28 to $46.12 \mathrm{Mg}$ of carbon per hectare on the soil surface horizon.
\end{abstract}

Keywords: Soil organic carbon, Clay minerals, Climate, Potential organic carbon loss, Golestan province. 


\section{Introduction}

Organic matter content of the most soils is less than $5 \%$, nevertheless this small amount of OC has a significant impact on soil properties. Positive effect of the soil organic matter has been proved in a variety of soils on soil properties (Rasmussen and Collins, 1991). Nonetheless, SOC has a negative impact on the environment by greenhouse gases effect on global climate change. For example, Paustian et al. (2000) estimated that $55 \mathrm{Pg} \mathrm{C}$ were released from the soil to the atmosphere during the $19^{\text {th }}$ and $20^{\text {th }}$ centuries because of agriculture.

Soil organic matter can be divided into labile or rapidly decomposed, and stable or slowly decomposed fractions. Soil carbon oxidized by neutral $\mathrm{KMnO}_{4}$, or permanganate-oxidizable carbon (POC), has been used as the index of labile carbon by several researchers.

Approximately soil provides $75 \%$ of the land carbon. SOC represents the largest terrestrial organic C pool and globally contains over 1550 Pg C (A Pg is equal to $1015 \mathrm{~g}$ or 1000 million metric tons) (Lal, 2008), and this pool attracts considerable attention because of its potential to sequester C (Baker et al., 2007). Many projects such as forestation and improving pasture cause increasing carbon storage in soil; on the other hand, SOC increase leads to improved structure, soil porosity and permeability (Kerr, 2001). The amount of SOC is controlled firstly by climatic factors (in most situations). Under similar climatic conditions, surface soil texture, SOC is started to control and accumulation. Furthermore, parent materials are the main compound in the accumulation and decomposition (Parton et al., 1987). Bravo et al, (2007) showed that the interaction between the climatic factor and the granulometric composition of the surficial horizon determine the content and SOC transformation. These researchers also reported the rainfall determines the volume, quality and amount of plant biomass mineralization which is one of the factors controlling SOC accumulation in soil.

Rasmussen and Collins (1991) found a positive effect of rainfall which was inversely related to rising temperatures of soil organic matter levels. Organic matter can adsorb cations anion through various mechanisms. This interaction includes columbic (hydrogen bonds, cationic and anionic exchange, ligand exchange, cation bridges) and non-columbic (van der waals) (Feng et al., 2005). Absorption of organic materials by minerals has been suggested as an important way to maintain and stabilize OC (Kalbitz et al., 2005). Organic compounds with minerals reduce microbial mineralization (Kalbitz et al., 2005). Soil mineralogy is important to estimate SOC in soil and maintenance (Tron et al., 1997). Clay minerals are components of mineral materials of soil, which play a special role in stabilizing the organic compounds (Martin and Haider, 1986). Clay minerals have high SSA and electric charge that enable them to enclose, and thereby, to stabilize organic matter.

Wiseman and Püttmann (2006) were observed in investigation relationship between mineral phases and OC preservation in several profiles that among the clay minerals kaolinite, illite and chlorite that having high amphoteric property in edges of minerals, have much more willing to absorbed OC compare with smectite minerals. Jardine et al., (1989) showed that amorphous and non-amorphous iron oxides and hydroxide have been preserved 50-70 percent of total solved OC adsorption in two different soils and also the remainder had been absorbed by other minerals, especially kaolinite clay particles. Wiseman and Püttmann (2005) were observed in investigation preservation of organic carbon in several soil samples in Germany, in the one sample they observed a weak relationship between SSA and SOC that indicates 
infiltration of organic material between the layers of minerals such as smectite and mixed layer mineral (illite-smectite). It appears that there is positive relationship to absorb between solved organic carbons and specific surface (Kennedy et al., 2002).

Aggregates have more than 90 percent of OC in surface soils and physical protection of organic materials within the aggregate is known as an important factor controlling the soil organic matter decomposition and degradation (Jastrow et al., 1996). Cambardella and Elliot (1993) and John et al. (2005) had showed that reducing the aggregate size, amount of OC also decreases. Ashagrie et al., (2007) observed that reducing the aggregate size, amount of organic carbon and nitrogen find increase. In general, SOC is stored in coarse aggregate, fine aggregates and particles smaller than $0.053 \mathrm{~mm}$ (silt + clay particles).

According to the results of Brodowski et al., (2006) clay + silt parts cannot contain a lot of organic carbon and bulk SOC (more than 90 percent) is stored in aggregate (Jastrow et al., 1996). According to Schlesinger definition (1999) carbon storage is responsible for the long-term storage of carbon in the oceans, soils, vegetation (especially forests and pastures) and the geological formation.

In recent years, consideration to soil organic matter in relation to increased carbon sequestration (Houghton, 2003) and achievement to increased soil carbon sequestration has been as an appropriate method for reducing the atmospheric $\mathrm{CO}_{2}$ concentration in the scientific community and the political world (Kimble et al., 2003). The objective of this study was to determine: 1 - The effect of mineral factors in OC stabilization and storage in a climo-sequence, 2- The role of climatic factors on the accumulation of organic matter in soil surface and 3- Investigating the role of organic materials on the soil physical and chemical properties.

\section{Material and methods}

\subsection{Location of the study area}

The study area is shown in Figure 1. The study area, comprising a climatic gradient in the range of $80 \mathrm{~km}$, is located in the eastern part of Golestan province, Iran.

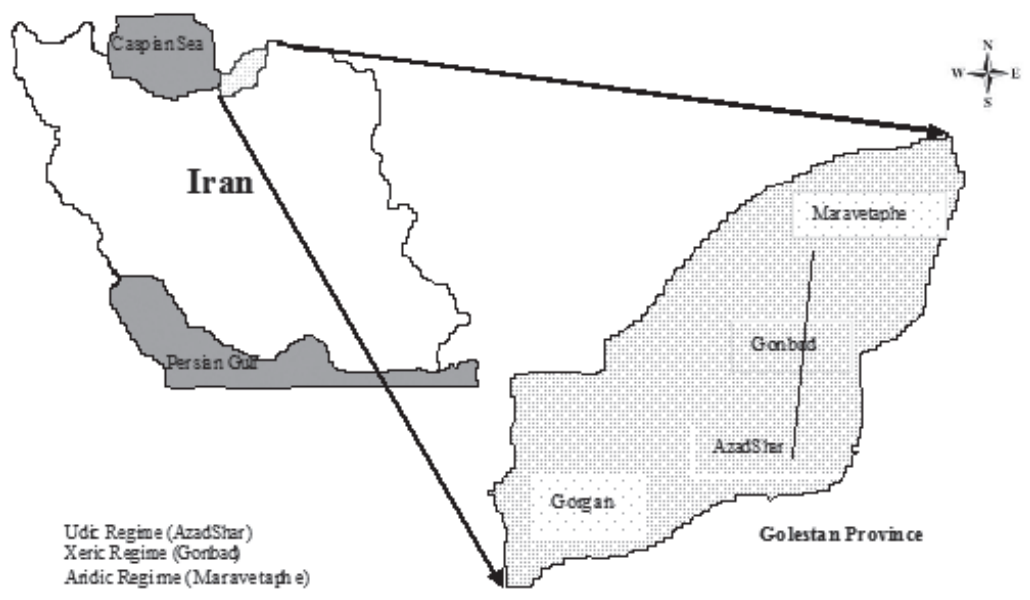

Figure 1. Geographical location of the study area. 
Soil parent materials are loess and reworked loess. The study areas included udic, aridic and xeric moisture regimes, and thermic and mesic temperature re- gimes. Summary of the climatic data of the soil study are given in Table 1.

Table 1. Climatic properties and soil classification (Soil Taxonomy, 2010) of soils studied.

\begin{tabular}{|c|c|c|c|c|c|c|c|}
\hline Sample & $\begin{array}{c}\text { Annual } \\
\text { precipitation } \\
(\mathbf{m m})\end{array}$ & $\begin{array}{c}\text { Annual } \\
\text { temperature } \\
\left(C^{\circ}\right)\end{array}$ & $\underset{\text { ET }^{\circ}}{(\mathbf{m m})}$ & $\begin{array}{l}\text { Predominant } \\
\text { climate }\end{array}$ & $\begin{array}{l}\text { Moisture- } \\
\text { Temperature } \\
\text { regimes }\end{array}$ & $\mathbf{P} / \mathbf{E T}^{\circ}$ & $\begin{array}{c}\text { Soil } \\
\text { classification }\end{array}$ \\
\hline 1 & 862 & 15 & 1077 & Moist & Udic-Mesic & 0.8 & $\begin{array}{c}\text { Typic } \\
\text { Argiudolls }\end{array}$ \\
\hline 2 & 735 & 17.5 & 1130 & Semi-Moist & $\begin{array}{l}\text { Xeric- } \\
\text { Thermic }\end{array}$ & 0.65 & $\begin{array}{c}\text { Typic } \\
\text { Haploxerolls }\end{array}$ \\
\hline 3 & 572 & 18.4 & 1144 & Mediterranean & $\begin{array}{l}\text { Xeric- } \\
\text { Thermic }\end{array}$ & 0.5 & $\begin{array}{c}\text { Typic } \\
\text { Haploxerepts }\end{array}$ \\
\hline 4 & 427 & 18.4 & 1067 & Semi-Arid & $\begin{array}{l}\text { Xeric- } \\
\text { Thermic }\end{array}$ & 0.4 & $\begin{array}{c}\text { Typic } \\
\text { Calcixerepts }\end{array}$ \\
\hline 5 & 386 & 18.4 & 1287 & Semi-Arid & $\begin{array}{l}\text { Aridic- } \\
\text { Thermic }\end{array}$ & 0.3 & $\begin{array}{c}\text { Typic } \\
\text { Haplocalcids }\end{array}$ \\
\hline 6 & 294 & 17.9 & 1176 & Semi-Arid & $\begin{array}{l}\text { Aridic- } \\
\text { Thermic }\end{array}$ & 0.25 & $\begin{array}{l}\text { Typic Haplo- } \\
\text { cambids }\end{array}$ \\
\hline 7 & 264 & 17.9 & 1320 & Arid & $\begin{array}{l}\text { Aridic- } \\
\text { Thermic }\end{array}$ & 0.2 & $\begin{array}{c}\text { Typic } \\
\text { Torriorthents }\end{array}$ \\
\hline
\end{tabular}

\subsection{Vegetation and land use}

Vegetation in the study area included shrubs and weed plants. To reduce the effect of different vegetation and land use, lands selected with the same land uses and vegetation.

\subsection{Field working and soil sampling}

According to purpose of the study i.e. carbon stock and mineral factors controlling organic carbon along precipitation and temperature gradients, the total number of 7 samples $(20-0 \mathrm{~cm})$ with three replications were collected in a climatic gradient. Soil samples from $0-20 \mathrm{~cm}$ were air-dried and sieved through a $2 \mathrm{~mm}$ sieve. The following analyses were performed: Particle size distribution was determined by the
Bouyoucos hydrometer method (Bouyoucos, 1962). Organic carbon was measured according to Nelson (1982). The soil pH was measured in saturation paste. Electrical conductivity was determined in the saturation paste extract (Page et al. 1982). Bulk density (BD) was measured by using method of Brasher et al. (1966).

Cation exchange capacity (CEC) was determined using sodium acetate $(\mathrm{NaOAc})$ at a $\mathrm{pH}$ of 8.2 (Chapman, 1965). The carbonate calcium was measured by using method of Page et al. (1982). Mean weight diameter (MWD) was measured using wet sieving (Kemper and Rosenau, 1986). Dithionite-extractable $\mathrm{Fe}$ (Fed) was measured for bulk soil samples $(<2$ $\mathrm{mm}$ ) using the method of Mehra and Jackson (1960). Oxalate-extractable $\mathrm{Fe}$ (Feo) was estimated using the ammonium oxalate extraction solution and the oxa- 
lic acid $(\mathrm{pH}=3)$ method was performed by Mckeague and Day (1966). Extracts were measured using atomic absorption spectrometry (Unicam AAB-919) and then iron concentration was calculated.

\subsection{Mineralogical analyses}

Removal of chemical cementing agents and separation of clay fractions was carried out according to Mehra and Jackson (1960), Kittrick and Hope (1963) and Jackson (1975). X-ray diffraction (XRD) studies were carried out using a Philips diffractometer on both fine and coarse clay fractions, while equal concentrations of clay suspensions were used for all samples in order to allow a more reliable comparison between relative peak intensities for different samples. The (001) reflections were obtained following $\mathrm{Mg}$ saturation, ethylene glycol solvation and $\mathrm{K}$ saturation. The Ksaturated samples were studied both after drying and heating at 330 and $550^{\circ} \mathrm{C}$ for $4 \mathrm{~h}$. To identify kaolinite in the presence of trioctahedral chlorite, samples were also treated with $1 \mathrm{~N} \mathrm{HCl}$ at $80^{\circ} \mathrm{C}$, overnight. The percentages of the clay minerals were estimated according to Johns et al., (1954).

\subsection{Organic carbon content in different aggregate sizes}

SOC in aggregate size was conducted after aggregate separation by wet sieving. The soils were wet sieved through a series of three sieves $(2,0.25$ and 0.053 $\mathrm{mm})$. The method used for aggregate size separation was performed by Cambardella and Elliot (1993). A 100-g subsample (air dried) was submerged for $5 \mathrm{~min}$ in room temperature deionized water, on top of the 2 $\mathrm{mm}$ sieve. Aggregations separation was achieved by manually moving the sieve up and down $3 \mathrm{~cm}$ with 50 repetitions during a period of $2 \mathrm{~min}$. After $2 \mathrm{~min}$ cycle, the stable $>2 \mathrm{~mm}$ aggregates were gently back- washed off the sieve into aluminum pan and other sieves similarly were washed. The aggregates were oven dried $\left(50^{\circ} \mathrm{C}\right)$, weighed and amount of organic carbon was measured in different aggregate sizes by using method of Nelson (1982). Aggregation was classified as coarse aggregation $(0.25-4 \mathrm{~mm})$ and fine aggregation (0.053-0.25 mm). The amount of organic carbon that was related to aggregation size finer than 0.053 $\mathrm{mm}$ (Clay + Silt particles) was subtracted from the total organic carbon.

\subsection{Specific surface area measurement}

Specific surface area was measured according to Carter et al., (1986). As organic material can affect estimation of SSA, it was first eliminated using peroxidation. For this, a $10 \%$ (by volume) solution of $\mathrm{H}_{2} \mathrm{O}_{2}$ was added continuously and the samples heated $\left(70^{\circ} \mathrm{C}\right)$ until conspicuous effervescence had stopped and the solution got clear. The method used to measure SSA was an adapted version that developed by Carter et al. (1986), which employs ethylene glycol monoethyl ether (EGME). This method allows the determination of the internal SSA of smectites. SSA was calculated from the formula below (equation 1):

$$
\mathrm{A}=\frac{\mathrm{W}_{\mathrm{EGME}}}{\text { Ws } \times 0.000286}
$$

Where A is SSA $\left(\mathrm{m}^{2} \mathrm{~g}^{-1}\right), \mathrm{W}_{\mathrm{EGME}}$ is the weight of EGME retained by the sample (g), Ws is the weight of the sample $(\mathrm{g})$ and 0.000286 is the weight of a monolayer of EGME $(\mathrm{g})$ on a square metre surface.

\subsection{Labile organic carbon measurement}

Separate soil samples $(<500 \mu \mathrm{m})$ containing $15 \mathrm{mg} \mathrm{C}$ were shake for 24 hour in $25 \mathrm{~mL}$ of $33 \mathrm{mM} \mathrm{KMnO}_{4}$ with repetition 12 (rpm). The oxidation of organic matter was measured by the change in $\mathrm{KMnO}_{4}$ con- 
centration, measured at $565 \mathrm{~nm}$ (Spectrophotometer), the $\mathrm{KMnO}_{4}$ concentration from the samples and blanks was determined using the standard calibration curve, and the results expressed as $\mathrm{mg} \mathrm{C}$ soil $^{-1}$. The amount of POC in the sample was calculated as below (equation 2):

POC $=\left(\frac{\mathrm{mg}}{\mathrm{g}}\right)=\frac{\left(\mathrm{mM} \mathrm{blank}-(\mathrm{mM} \text { sample }) \times\left(\frac{50}{2}\right) \times 25 \times 9\right.}{1000\left(\frac{\mathrm{ml}}{\mathrm{L}}\right) \times \text { wt of sample }(\mathrm{g})}$

Where mM Blank and mM Sample are the concentrations $\left(\mathrm{mmol} \mathrm{L}^{-1}\right)$ of $\mathrm{KMnO}_{4}$, the blank and sample, respectively, determined from the standard regression curve: $50 / 2=$ the dilution factor $\left(\mathrm{mL} \mathrm{mL}^{-1}\right)$; $25=$ the volume $(\mathrm{mL})$ of $\mathrm{KMnO}_{4}$ added to the soil sample; $9=$ the amount of $\mathrm{C}$ oxidized for every mole of $\mathrm{KMnO}_{4}\left(\mathrm{~g} \mathrm{~mol}^{-1}\right.$ or $\left.\mathrm{mg} \mathrm{mmol}^{-1}\right)\left(\right.$ When $\mathrm{Mn}^{+7} \mathrm{O}_{4}^{-}$is reduced to $\mathrm{Mn}^{+4} \mathrm{O}_{2}$ and $\mathrm{C}$ is oxidized from the natural state ( 0$)$ to $\mathrm{C}^{+4}$ three moles of $\mathrm{C}$ are oxidized for every four moles of $\mathrm{Mn}^{+7}$ reduced) (Tirol-Padre and
Ladha, 2004). Maximum loss of OC for each soil was estimated through POC and BD.

\subsection{Data analysis}

Statistical analyses of the results were conducted using SAS program (1999). Correlation and linear regressions were performed between $\mathrm{OC}$, MWD, POC, Feo, Fed, SSA and P/ET. Analysis of variance was used to compare the amount of the organic carbon in different aggregation sizes and the amount of the losses potential organic carbon in different profiles. Moreover, the LSD procedure was conducted to compare means of the organic carbon in different aggregations size and the amount of the losses potential organic carbon in different profiles at $p<0.01$.

\section{Results and discussion}

The results of physico-chemical properties of the soils studied have been presented in Table 2 .

Table 2. Physico-chemical properties, Dithionite-extractable Fe (Fed), oxalate-extractable Fe (Feo) and SSA of the soils studied.

\begin{tabular}{|c|c|c|c|c|c|c|c|c|c|c|c|c|}
\hline Sample & $\begin{array}{l}\text { OC } \\
\%\end{array}$ & $\begin{array}{c}\text { EC } \\
(\mathrm{dS} \text { m-1) }\end{array}$ & $\mathrm{pH}$ & Clay & Silt & Sand & $\begin{array}{c}\text { CCE } \\
\%\end{array}$ & $\begin{array}{l}\text { CEC } \\
\text { (cmol } \\
\mathrm{kg} \mathrm{-1)}\end{array}$ & $\begin{array}{c}\text { Fed } \\
\%\end{array}$ & $\begin{array}{c}\text { Feo } \\
\%\end{array}$ & $\underset{(\mathrm{m} 2 \mathrm{~g}-1)}{\mathrm{SSA}}$ & Texture \\
\hline 1 & 2.74 & 0.80 & 6.9 & 32.50 & 60.00 & 7.50 & 2.1 & 27.8 & 0.03 & 0.42 & 126.61 & $\mathrm{SiCL}$ \\
\hline 2 & 1.63 & 0.89 & 7.5 & 40.80 & 48.37 & 10.83 & 2.6 & 34.8 & 0.31 & 0.50 & 132.70 & $\mathrm{SiCL}$ \\
\hline 3 & 1.66 & 1.40 & 7.5 & 22.50 & 45.00 & 32.50 & 7.6 & 17.6 & 0.80 & 0.17 & 51.50 & $\mathrm{~L}$ \\
\hline 4 & 1.64 & 1.42 & 7.5 & 32.50 & 50.00 & 17.50 & 15.1 & 22.2 & 0.41 & 0.10 & 84.73 & $\mathrm{SiCL}$ \\
\hline 5 & 0.85 & 1.60 & 7.5 & 25.83 & 63.33 & 10.83 & 10.1 & 18.6 & 0.44 & 0.06 & 78.69 & $\mathrm{SiL}$ \\
\hline 6 & 0.73 & 3.28 & 7.6 & 20.80 & 65.90 & 13.30 & 17.6 & 12.8 & 0.27 & 0.06 & 55.63 & $\mathrm{SiL}$ \\
\hline 7 & 0.34 & 3.13 & 7.6 & 32.50 & 63.33 & 4.20 & 19.6 & 9.6 & 0.01 & 0.05 & 51.73 & $\mathrm{SiCL}$ \\
\hline
\end{tabular}


Electrical conductivity (EC) of the soils showed a reverse trend with increasing temperature and decrease in rainfall. EC varied from $0.8 \mathrm{dsm}^{-1}$ in soil 1 to 3.28 $\mathrm{dsm}^{-1}$ in soil 6. $\mathrm{pH}$ was in weak alkalinity range due to the parent materials rich in lime. The lower $\mathrm{pH}$ in soil 1 is because of the increase in organic carbon content which consequently increases $\mathrm{CO}_{2}$ that can control the $\mathrm{pH}$. Natural phenomenon such as free $\mathrm{CO}_{2}$ due to the plant root and microbial respiration also can be the controlling factors of soil $\mathrm{pH}$ (USDA - NRCS, 1999). Soil texture varied from loam- to silty clay loam. In addition, with temperature increase and rainfall decrease, silt particles increased. CEC decreased from $34.8 \mathrm{cmol} \mathrm{Kg}^{-1}$ in soil 2 to $9.6 \mathrm{cmol} \mathrm{Kg}^{-1}$ in soil 7. Considerable increase in clay percentage in soil 2 could explain the increase in CEC in soil 7. The amount of the $\mathrm{CaCO}_{3}$ is $2.1 \%$ in soil 1 and $10.6 \%$ in soil 7 that shows non-leaching environment from surface horizons. Motamed (1997) states the loess materials contain the high lime percentage.

\subsection{Organic carbon stocks in different aggregates}

Organic carbon is trapped in different aggregates sizes including coarse aggregates $(0.25-4 \mathrm{~mm})$, fine aggregates $(0.25-0.053 \mathrm{~mm})$ and aggregate smaller than $0.053 \mathrm{~mm}$. The amounts of organic carbon for each size were measured in each sample (Table 3).

Table 3. Amounts of organic carbon measured in different separate aggregates (g kg-1).

\begin{tabular}{lccccccc}
\hline \multirow{2}{*}{ Aggregate size } & \multicolumn{7}{c}{ Soil profiles } \\
\cline { 2 - 8 } & $\mathbf{1}$ & $\mathbf{2}$ & $\mathbf{3}$ & $\mathbf{4}$ & $\mathbf{5}$ & $\mathbf{6}$ & $\mathbf{7}$ \\
\hline$>0.053 \mathrm{~mm}$ & 9.15 & 0.85 & 0.55 & 3.65 & 2.60 & 0.55 & 1.60 \\
$0.053-0.25 \mathrm{~mm}$ & 3.15 & 5.35 & 4.45 & 1.10 & 2.15 & 1.35 & 0.85 \\
$0.25-4 \mathrm{~mm}$ & 15.05 & 10.10 & 11.60 & 11.65 & 3.80 & 5.45 & 0.95 \\
OC $\left(\mathrm{g} \mathrm{kg}^{-1}\right)$ & 27.40 & 16.30 & 16.60 & 16.40 & 8.55 & 7.35 & 3.40 \\
MWD & 1.72 & 0.57 & 0.64 & 1.44 & 0.47 & 0.36 & 0.17 \\
\hline
\end{tabular}

Analysis of variance was performed to compare the amount of different organic carbon in soils of different sizes (Table 4).

Table 4. Analysis of variance of organic carbon in samples and different size fractions.

\begin{tabular}{lccc}
\hline S.O.V & df & MS & F \\
\hline Sample & 6 & 42.41 & $282.73^{\text {** }}$ \\
Size & 2 & 151.83 & $1012.2^{\text {** }}$ \\
Sample $\times$ size & 12 & 16.78 & $111.86^{\text {** }}$ \\
Error & 21 & 0.15 & - \\
Total & 41 & - & - \\
\hline
\end{tabular}

${ }^{* *}$ Correlation is significant at $\mathrm{p}<0.01$.
The result showed that the amount of organic carbon among samples and different sizes had significant difference and also mutual effect of sample size on the amount of organic carbon was significant $(p$ $<0.01$ ). Comparison of the amount of organic carbon in different samples were carried out for each aggregate size separately (Fig 2a) and also comparison of the organic carbon content in different sizes in each sample (Fig 2b) was performed with LSD test in $0.01 \%$ probability level. 

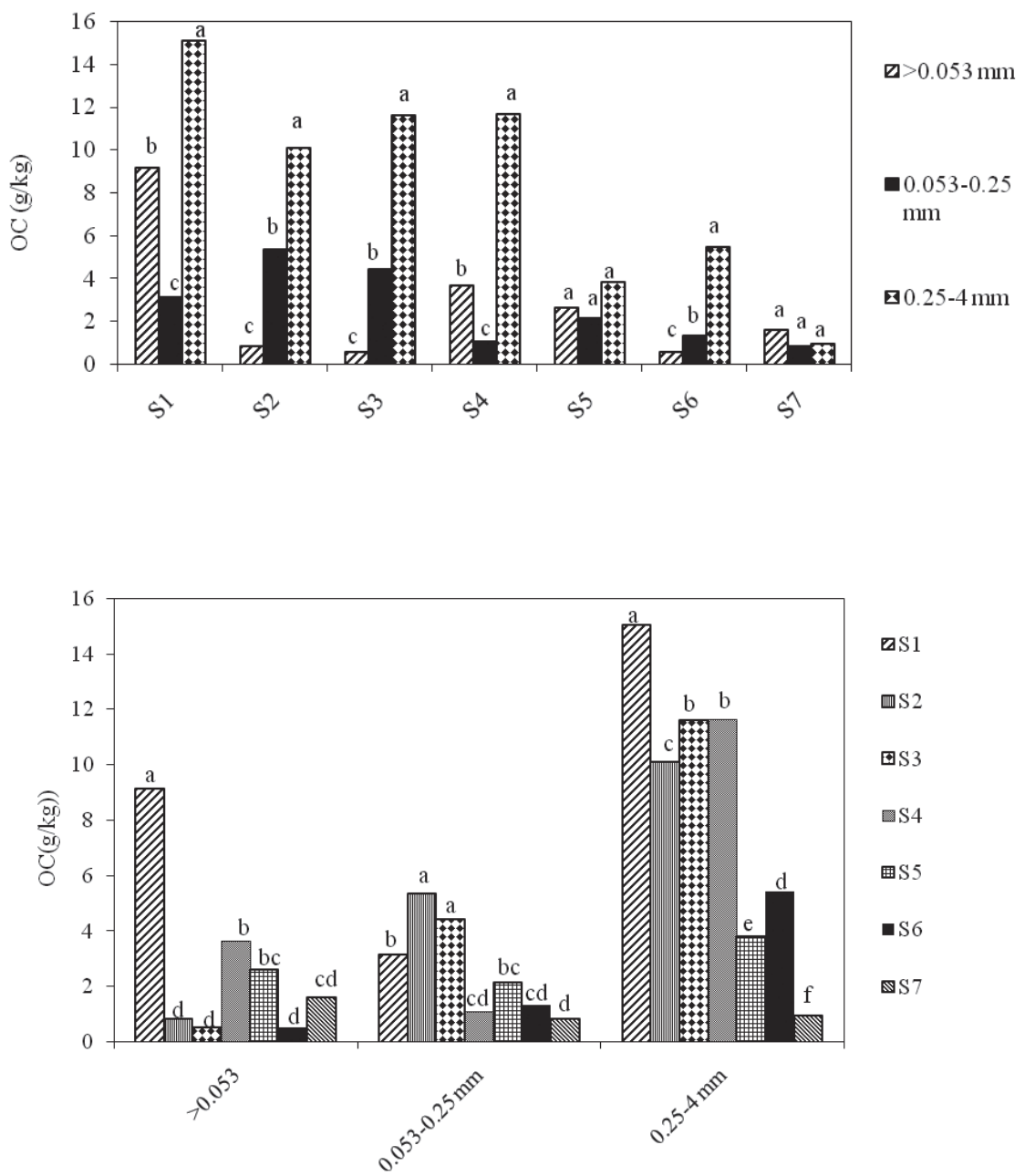

Figure 2. Average comparison for the amount of organic carbon.

Higher content of fresh organic material was present in coarse aggregates. According to (Figure 2a and 2b) with increasing aggregates size, the OC content increased, which is consistent with other findings (Cambardella and Elliot, 1993; John et al., 2005). The aggregates smaller than $0.053 \mathrm{~mm}$ have the less portion of the organic material (except samples 1, 4, 5, 7). Among the amount of preserved OC in particles size of different aggregates have significative difference in samples 1 ,
2, 3, 4, $6(p<0.01)$ but in samples 5 and 7 have not found the significative difference in amount of OC. Coarse aggregate sizes $(0.25-4 \mathrm{~mm})$ in all of the samples have the highest amount of OC (except sample 5 and 7). Consequently, SOC has been preserved in coarse aggregates, fine aggregates and particles less than $0.053 \mathrm{~mm}$. Based on the result of Brodowski et al., (2006), the silt plus clay part cannot contain more OC and the main part of SOC (more than $90 \%$ ) has been 
preserved in aggregates (Jastrow et al., 1996). Figure $2 \mathrm{~b}$ reveals the mean comparison for the amount of OC in sizes of the same aggregates for different samples. According to Figure 2b, among all samples, the highest content of carbon stock was present in the aggregates $0.25-4 \mathrm{~mm}$ and $<0.053 \mathrm{~mm}$. In general, aggregates $<$ $0.053 \mathrm{~mm}$ contain the lowest amount of OC stock and coarse aggregates $(0.25-4 \mathrm{~mm})$ contain the highest
OC stock. An et al. (2010) concluded that in all land uses, coarse aggregates ( $\mu 250-630<630-1000)$ contained higher amount of the SOC than fine aggregates $(\mu \mathrm{m} 63<63-250<10-250)$.

Organic material is one of the main factors in increasing aggregate stability. Figure 3 shows the relationship between aggregate stability (MWD) and amount of the OC in surface samples of soils studied.

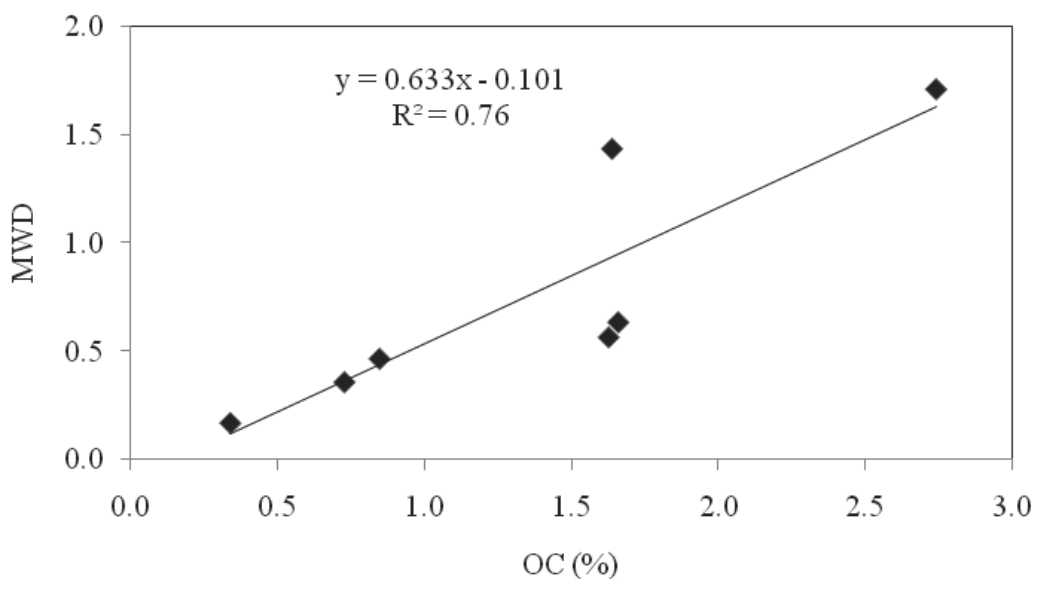

Figure 3. The relationship between aggregate stability (MWD) and OC content.

According to Figure 3, with increasing OC content, aggregate stability (MWD) increases as well. Christensen (1986) has reported the presence of a direct correlation between amount of the total OC and aggregate stability. Mbagwu and Piccolo (1998) found out a positive and significant correlation between fine aggregates and Humic acid content.

3.2 Organic carbon stock and its relationship with clay minerals

The results of mineralogy of different samples showed that illite, chlorite, kaolinite, smectite, ver- miculite, and mixed layer minerals were present in studied samples (Table 5 ). The results showed that by decreasing rainfall there is an increase in the inherited minerals. Due to the presence of loess parent materials, illite minerals are the most dominant clay minerals (Ajami and Khormali, 2009). Khormali et al., (2005) also states the dominance of illite and chlorite in parent material loess of Golestan province. 
(Table 5. Mineralogy of the studied soils.)

\begin{tabular}{lccccccc}
\hline Sample & $\begin{array}{c}\text { Sequence of } \\
\text { minerals }\end{array}$ & Illite & Chlorite & Smectite & Vermiculite & Kaolinite & Mixed layer \\
\hline 1 & $\mathrm{I}>\mathrm{S}=\mathrm{V}>\mathrm{Ch}=\mathrm{K}$ & $11(30)$ & $4(10)$ & $9(25)$ & $9(25)$ & $4(10)$ & - \\
2 & $\mathrm{I}>\mathrm{S}>\mathrm{Ch}>\mathrm{M}=\mathrm{K}$ & $14(35)$ & $8(20)$ & $10(25)$ & - & $4(10)$ & $4(10)$ \\
3 & $\mathrm{I}>\mathrm{Ch}>\mathrm{K}>\mathrm{S}>\mathrm{M}$ & $10(45)$ & $6(25)$ & $2(10)$ & - & $3(15)$ & $1(5)$ \\
4 & $\mathrm{I}>\mathrm{Ch}>\mathrm{K}>\mathrm{S}$ & $14(43)$ & $11(34)$ & $3(8)$ & - & $5(15)$ & - \\
5 & $\mathrm{I}>\mathrm{Ch}>\mathrm{K}$ & $13(50)$ & $8(30)$ & - & - & $5(20)$ & - \\
6 & $\mathrm{I}>\mathrm{Ch}>\mathrm{K}$ & $9(45)$ & $7(35)$ & - & - & $4(20)$ & - \\
7 & $\mathrm{I}>\mathrm{Ch}>\mathrm{S}=\mathrm{K}$ & $16(50)$ & $10(30)$ & $3(10)$ & - & $3(10)$ & - \\
\hline
\end{tabular}

The numbers in the parentheses are the mineral percentage of the clay fraction. $\mathrm{I}=$ Illite, $\mathrm{V}=$ Vermiculite, $\mathrm{Ch}=$ Chlorite, $\mathrm{S}=$ Smectite, $\mathrm{K}=$ Kaolinite, $\mathrm{M}=$ Mixed layer.

The SOC was correlated with clay mineralogy, i.e. illite, chlorite, kaolinite, and smectite separately. Vermiculite and mixed layer minerals exist in little amounts.
Shahriyari (2009) showed that the ratio of OC on clay can represent the part of the soil particles that is related to organic carbon. Table 6 stands for the results of the correlation studied.

Table 6. Results of relationship between soil minerals with SOC and (clay/ OC) ratio.

\begin{tabular}{lccccc}
\hline \multirow{2}{*}{ Minerals } & No. Samples & \multicolumn{2}{c}{ SOC (\%) } & \multicolumn{2}{c}{ Ratio (clay/ OC) } \\
\cline { 3 - 6 } & 7 & $\begin{array}{c}\text { Correlation } \\
\text { coefficient }\end{array}$ & $\begin{array}{c}\text { Significant } \\
\text { probability }\end{array}$ & Correlation & Significant probability \\
\hline Illite & -0.87 & 0.01 & 0.53 & 0.21 \\
Smectite & 5 & 0.59 & 0.29 & -0.33 & 0.58 \\
Chlorite & 7 & -0.79 & 0.05 & 0.31 & 0.49 \\
Kaolinite & 7 & -0.41 & 0.36 & -0.27 & 0.55 \\
\hline
\end{tabular}

The relation between illite percentages and SOC at surface $(1 \%)$ was significant and showed the negative correlation. This mineral existed in all samples. There was no significant relationship between illite percentage and the $\mathrm{OC}$ of the clay fraction.

Moreover, there was not any significant relationship between smectite content and OC. A significant relationship was observed between chlorite content and SOC in the level (5\%). There was not any significant relationship between kaolinite content and SOC. This mineral was present in all samples. The result revealed that except for the illite and chlorite minerals, none of the minerals had a significant relation with OC. In addition, none of the minerals had the significant relationship with Clay/OC ratio. Illite and chlorite minerals had the highest correlation with $\mathrm{OC}$ according to Wiseman and Püttmann (2006). They expressed that illite and chlorite by causing high amphoteric properties in the broken edges tend to absorb the OC. Kaolinite mineral has the lowest correlation with SOC. This 
could be related to its little SSA and weak exchange properties.

Shahriyari (2009) did not find any significant relationship between SOC and kaolinite, chlorite, smectite, illite, vermiculite and mixed layer minerals. Based on the results, Clay/OC ratio had a significant relationship with chlorite, smectite and mixed layer minerals. In the present study, rainfall and temperature were the main controlling factors of SOC. Bravo et al. (2007) expressed that the soil organic material is controlled by climatic factor essentially under the same climate situation; the texture of soil surface cause the accumulation of the organic material.
3.3 The relationship between soil organic carbon and iron oxide and hydroxides

The amount of the extractable iron with ammonium oxalate and sodium dithionite were determined and reported as iron oxides in Table 2.

The analysis of the relationship between SOC and Feo showed a significant and positive relation. The correlation coefficient was 0.73 in the $1 \%$ level (Figure 4a). The relationship between SOC and Fed was not significant (Figure 4b).
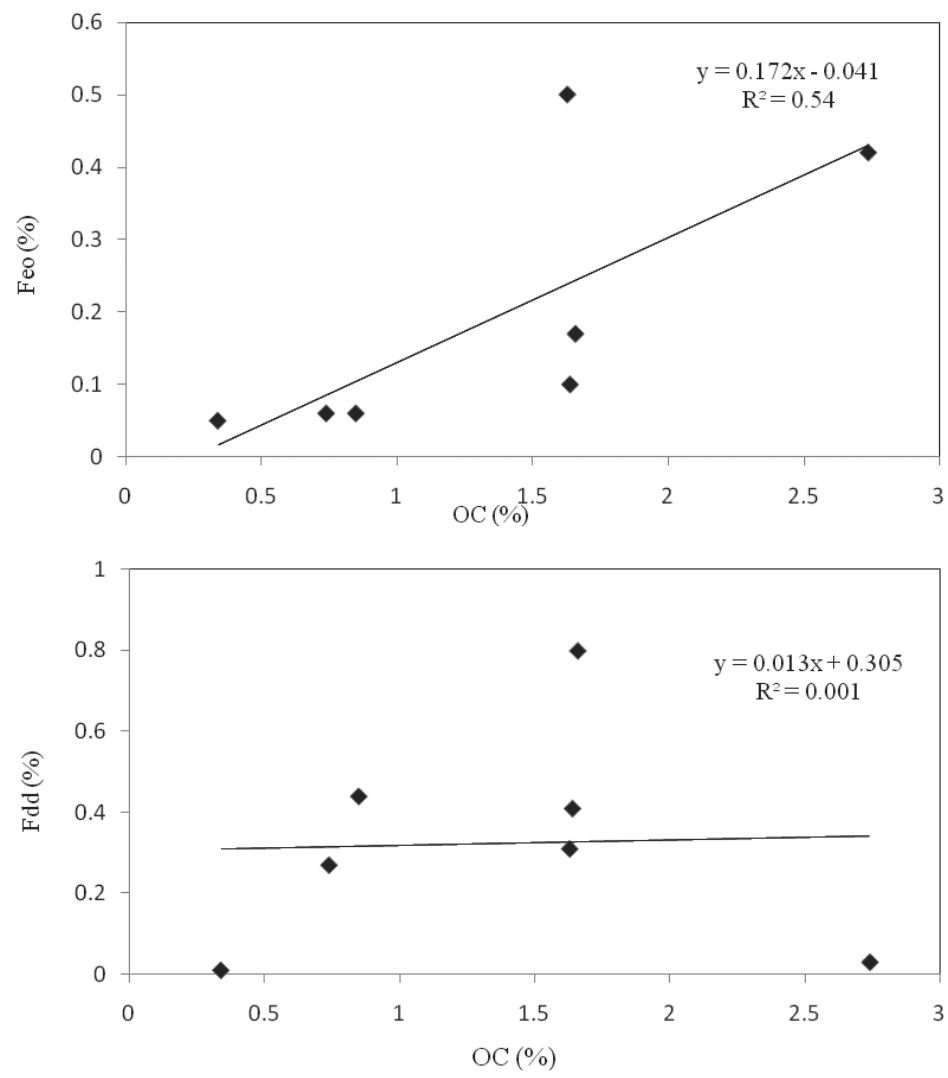

Figure 4. Relationship between SOC with a) Feo and b) Fed. 
The soils with different charge such as Oxisols and Aridisols have the weak relationship with the amount of organic material since organic material is fixed in these soils with iron oxides and allophane (Martin and Haider, 1986). According to Figure 4a, 55\% of Feo controls the OC.

Jardine (1989) showed that amorphous and nonamorphous iron oxides and hydroxides in two different soils kept $50-70 \%$ of solution OC. The remaining portion had been adsorbed, by other minerals and clay particles especially kaolinite. Shahriyari (2009) studying the Mollisols and Mollic subgroups, expressed the relation between SOC and Feo and Fed was not significant. Wiseman and Püttmann (2005) expressed there was a significant relation between the amount of $\mathrm{OC}$ and Fed and Feo showing the importance of oxides in OC fixation. Probably the relation between fed and the amount of the $\mathrm{OC}$ is related to presence of amorphous iron in the studied soils and the high affinity for OC fixation. The desirable drainage of studied soils can stabilize high amount of iron oxides.
The results showed that the amount of iron oxides decrease under undesirable drainage situation (Rich and Obenshain, 1995).

\subsection{The relationship between soil organic carbons and soil specific surface area}

The results of the SSA of samples are presented in Table 2. Christensen (1992) has suggested the calculation of SSA for clay and fine silt in soils. Therefore, Clay/OC ratio and Silt+Clay/OC ratio were correlated with the soil specific surface area (Table 2). The result of SOC and soil specific surface area showed that the relationships between these two factors were significant and there was a positive correlation (Figure 5). Wiseman and Püttmann (2005) expressed that just SSA for the changing of OC was not enough. Also this group of researchers in studying relation of specific surface with amount of $\mathrm{OC}$ in $\mathrm{B}$ and $\mathrm{C}$ horizons in Umbrisol found the significative correlation between two factors.

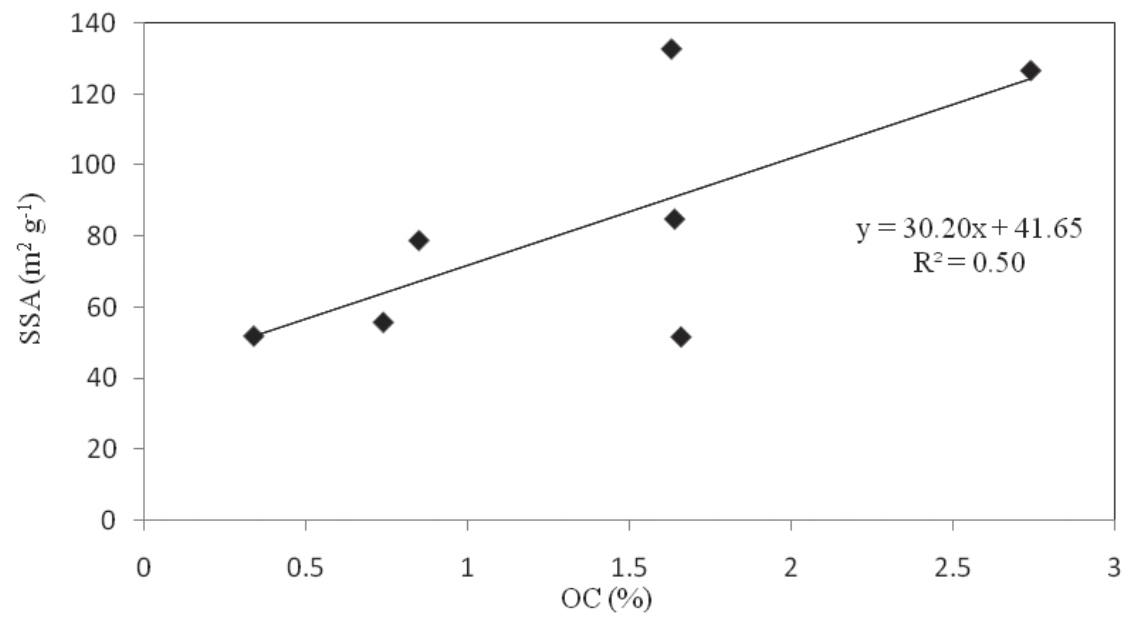

Figure 5. Relationship between SOC and SSA. 
According to the above explanations, the relationship between Clay/OC ratio and specific area was not significant (Figure 6a). There was not any significant relationship between SSA and silt+clay/OC ratio (Figure 6b).
3.5 Estimating the different types of organic carbon and total soil carbon stock

F or this propose, the amount of oxidizable OC with potassium permanganate was evaluated for the soil studied (Table 7).
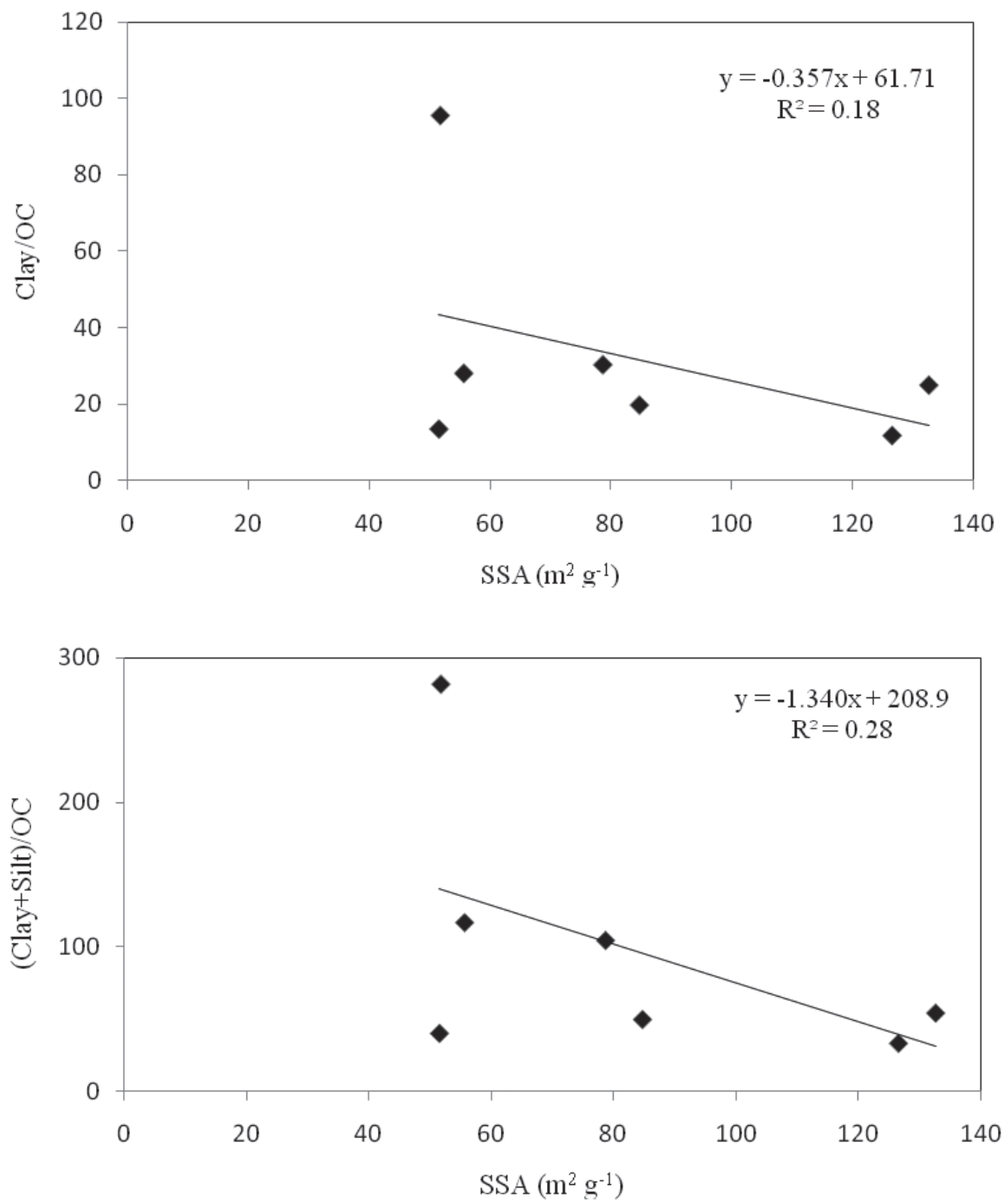

Figure 6. Relationship between SSA and a) ratio of clay/OC and b) ratio of silt+clay/OC. 
(Table 7. Labile OC and potential loss of OC, inorganic carbon and estimated stored total carbon in the soils studied.)

\begin{tabular}{|c|c|c|c|c|c|c|}
\hline Sample & $\begin{array}{c}\text { Soil } \\
\text { organic } \\
\text { carbon \% }\end{array}$ & $\begin{array}{l}\text { Labile organic } \\
\text { carbon }\left(\mathrm{g} \mathrm{kg}^{-1}\right)\end{array}$ & $\begin{array}{c}\text { Inorganic } \\
\text { carbon } \\
\left(\mathrm{g} \mathrm{kg}^{-1}\right)\end{array}$ & $\begin{array}{c}\text { BD } \\
\left(\mathrm{kg} \mathrm{m}^{-3}\right)\end{array}$ & $\begin{array}{c}\text { potential loss of } \\
\text { organic carbon } \\
(\mathrm{Mg} / \mathrm{ha} / \mathbf{2 0 c m})\end{array}$ & $\begin{array}{c}\text { Stored total } \\
\text { carbon }(\mathrm{g} \\
\left.0.2 \mathrm{~m}^{-3}\right)\end{array}$ \\
\hline 1 & 27.4 & 16.64 & 2.55 & 1380 & 46.12 & 8265.5 \\
\hline 2 & 16.3 & 11.38 & 3.15 & 1840 & 41.89 & 7139.2 \\
\hline 3 & 16.6 & 7.75 & 9.15 & 1410 & 21.86 & 7254.4 \\
\hline 4 & 16.4 & 8.49 & 18.15 & 1530 & 25.98 & 10561.9 \\
\hline 5 & 8.5 & 5.46 & 12.15 & 1520 & 16.60 & 6262.4 \\
\hline 6 & 7.3 & 3.82 & 21.15 & 1500 & 11.45 & 8521.1 \\
\hline 7 & 3.4 & 0.49 & 23.55 & 1300 & 1.28 & 6998.9 \\
\hline
\end{tabular}

SOC decreased by decreasing rainfall and increasing temperature. The lowest amount of labile OC found was $0.49 \mathrm{~g} \mathrm{~kg}^{-1}$. This sample had the lowest amount of SOC (Sample 7). The highest amount of labile OC $16.64 \mathrm{~g} \mathrm{~kg}^{-1}$ was related to the sample containing the highest SOC (Sample 1). Lal et al., (1995) expressed that the majority of the labile and non-labile OC are related to Mollisols and Inceptisols, respectively. This amount of non-labile OC is reasonable in these soils. The potential OC loss is variable between 1.28 to $46.12 \mathrm{Mg} \mathrm{h}^{-1}$ for $20 \mathrm{~cm}$ depth. The amount of OC loss potential in soils containing the fresh and decomposable organic materials is higher. Controlling this phase of $\mathrm{OC}$ is therefore very essential since it determines the amount of the released carbon into the atmosphere (Table 8).
The results of analyses of variance between different amounts of OC loss potential for each sample showed a significant difference.

Table 8. Analyses of variance of the loss potential of organic carbon in soils studied.

\begin{tabular}{lccc}
\hline S.O.V & df & MS & F \\
\hline Sample & 6 & 515.06 & $12.21^{* *}$ \\
Error & 7 & 42.15 & - \\
\hline
\end{tabular}

** Correlation is significant at $p<0.01$

Figure 7 shows the results of the mean comparison for the loss potential of OC for different samples. As observed, the highest and the lowest average are related to sample 7 and 1 . 


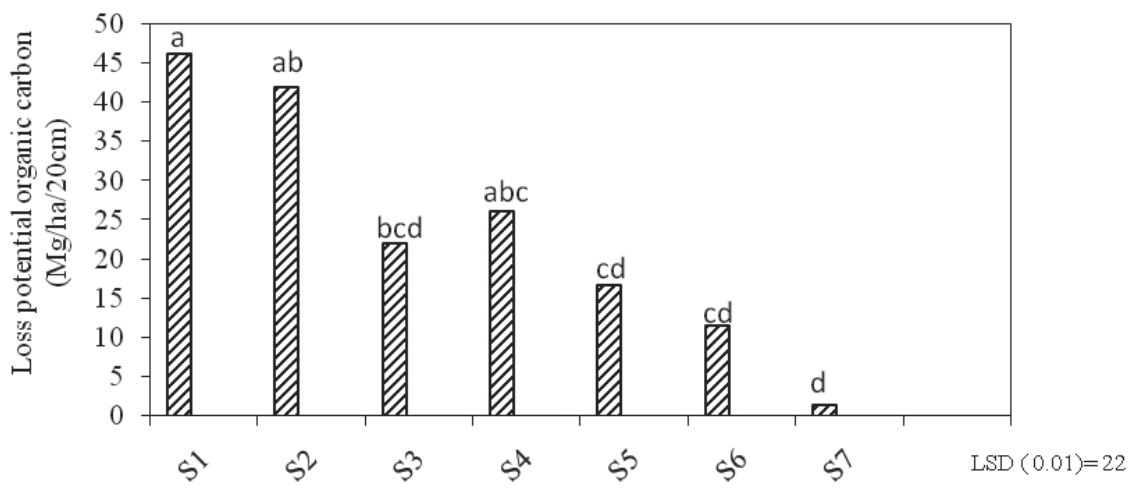

Figure 7. Mean comparison for the loss potential of OC for different samples. (Columns with similar letter do not have significant difference in probability level of $1 \%$.

Since organic materials increase with temperature therefore the loss potential of $\mathrm{OC}$ has a positive relaincrease and rainfall decrease (climate index $\mathrm{P} / \mathrm{ET}^{\circ}$ ), tionship with climate index (Figure 8).

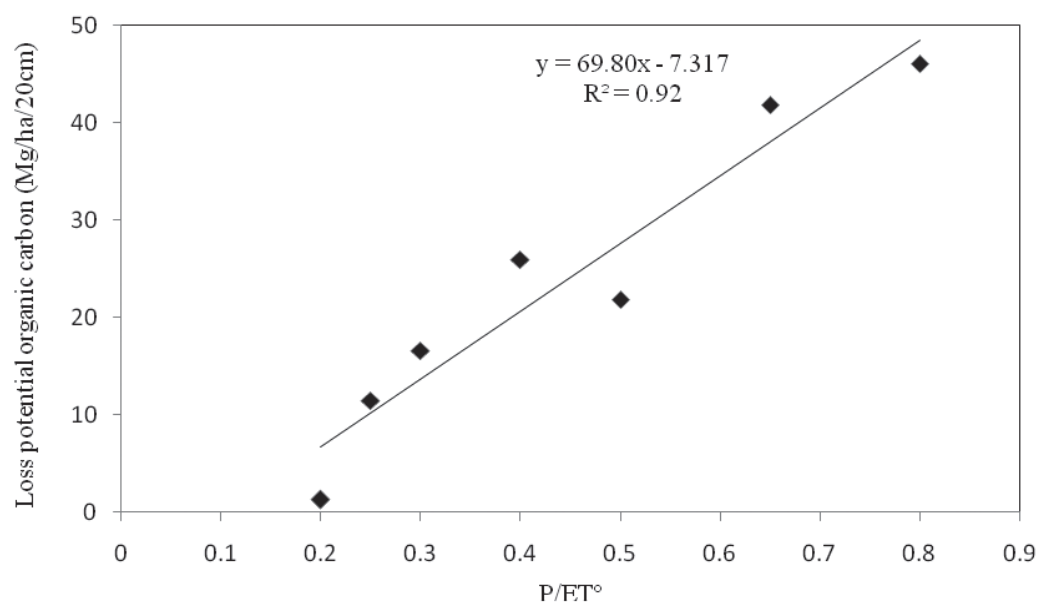

Figure 8. Relationship between climatic index and loss potential of organic carbon.

3.6 Estimating the amount of total organic carbon stock

Total OC stock was calculated using inorganic carbon (CCE), $\mathrm{BD}$, and the $\mathrm{OC}$ at the $20 \mathrm{~cm}^{2}$ for each sample (Table 7). The lowest amount of total soil OC stock equals $6262.4 \mathrm{~g}$ in $20 \mathrm{~cm}^{3}$ related to sample 5 and the highest amount equals $10561.9 \mathrm{gr}$ in $20 \mathrm{~cm}^{3}$ related to sample 4. Sample 4 has the highest total carbon stock among studied samples. Both high inorganic carbon $\left(\mathrm{CaCO}_{3}\right)$ and $\mathrm{OC}$ were high in this sample. The important part of total carbon stock in most of these samples 
is related to inorganic carbon. Thomson et al., (2008) showed that the soil carbon sequestration arrives to 0.5 to 0.7 Giga ton carbons in year in agricultural soils (0.21 Giga ton carbons in year), reforestation ( 0.31 Giga ton carbons in year) and pasture (0.15 Giga ton carbons in year) in the middle of 21 century.

\section{Conclusions}

The results obtained from the seven soils investigated showed that there is a strong relationship between OC content and climatic factors and also the relationship between $\mathrm{OC}$ content and mineral factors has been overemphasized in the literature. As a matter of fact, in a climatic gradient primarily climatic factor controlled OC content mineralization and accumulation. As shown here, such mineral interactions may play a significant role in OC stabilization, by forming complexes or aggregates which helps to protect organic material from mineralization. In light of the results, Aggregate formation was associated with increased C storage as $\mathrm{C}$ contents increased with aggregate size in most cases and $\mathrm{C}$ contents in all aggregate fractions. The important part of total $\mathrm{C}$ stock in most of these samples is related to inorganic $\mathrm{C}$. As a result, pastures have the controlling role to achieve this goal. Appropriate management of pastures therefore is an effective strategy in preventing the carbon loss by increasing the soil $\mathrm{C}$.

\section{References}

Ajami, M., Khormali, F. 2009. Clay mineralogy as an evidence of land degradation on loess hillslopes. J. of Water and Soil Conservation. 16, 61-84. (In Persian).

An, S., Mentler, A., Mayer, H., Blum, W.E.H., 2010. Soil aggregation, aggregate stability, $\mathrm{OC}$ and nitrogen in different soil aggregate fractions under forest and shrub vegetation on the Loess Plateau, China. Catena. 81, 226-233.

Ashagrie, Y., Zech, W., Guggenberger, G., Mamo, T. 2007. Soil aggregation, and total and particulate organic matter following conversion of native forests to continuous cultivation in Ethiopia. Soil and Tillage Reserch. 53, 215-230.

Baker, J.M., Ochsner, T.E., Venterea, R.T., Griffis, T.J. 2007. Tillage and soil carbon sequestrationwhat do we really know?. Agric. Ecosyst. Environ. $118,1-5$.

Blair, G.J., Lefroy, R.D.B., Lise, L. 1995. Soil carbon fractions based on their degree of oxidation, and the development of a carbon management index for agricultural systems. Australian J. Agric. Res. 46, 1459-1466.

Bouyoucos, G.J. 1962. Hydrometer method improved for making particle size analysis of soils. Agron. J. 54, 464-465.

Brasher, B.R., Franzmeier, D.P., Valassis, V., Davidson, S.E. 1966. Use of Saran resin to coat natural soil clods for Bulk-density water retention measurements. Soil Sci. 101,108.

Bravo, O., Balanco, M.D.C., Amiotti, N. 2007. Control factors in the segregation of Mollisols and Aridisols of the semiarid-arid transition of Argentina. Catena. 70, 220-228.

Brodowski, S., John, B., Flessa, H., Amelung, W. 2006. Aggregate- occluded black carbon in soil. Eur. J. Soil. Sci. 57, 539- 546.

Cambardella, C.A., Elliot, E.T. 1993. Carbon and nitrogen distributions in aggregates from cultivated and grassland soils. Soil Sci. Soc. Am. J. 57, 1071-1076.

Carter, D.L., Mortland, M.M., Kemper, W.D. 1986. Specific surface area. In: Methods of Soil Analysis: Part 1, Physical and Mineralogical Methods, 2nd edn (ed. A. Klute). American Society of 
Agronomy and Soil Science Society of America, Madison, WI. pp. 413-423.

Chapman, H.D. 1965. Cation exchange capacity. In: Methods of Soil Analysis. Part 2. Black, C. A. (Ed.). American Society of Agronomy, Madison, Wisconsin, USA.

Christensen, B.T. 1992. Physical fractionation of soil and organic matter in primary particle size and density separates. Adv. Soil Sci. 20, 1-90.

Christensen, B.T. 1986. Straw incorporation and soil organic matter in macroaggregates and particle size separates. J. Soil Sci. 36, 219-229.

Day, P.R. 1955. Particle fractionation and particle-size analysis. In: Black, C. A. (Ed.), Methods of Soil Analysis. Part I. Agronomy 9, Soil Sci. Soc. Am. Madison, WI. pp. 545-567.

Feng X., Simpson, A.J., Simpson, M.J. 2005. Chemical and mineralogical controls on humic acid sorption to clay mineral surfaces. Org. Geochem. $36,1553-1566$.

Houghton, R.A. 2003. Why are estimates of the terrestrial carbon balance so different?. Global Change Biology. 9, 500-509.

Jackson, M.L. 1975. Soil Chemical Analysis. Advanced Course. University of Wisconsin, College of Agriculture, Department of Soils, Madison, Wisconsin, USA.

Jardine, P.M., Weber, N.C., McCarthy, J.F. 1989. Mechanisms of dissolved organic carbon adsorption on soil. Soil Sci. Soc. Am. J. 53, 1378-1385.

Jastrow, J.D., Boutton, T.W., Miller, R.M. 1996. Carbon dynmics of aggregate-asociated organic matter estimated by carbon-13 natural abundance. Soil Sci. Soc. Am. J. 60, 801-807.

John, B., Yamashita, T., Ludwig, B., Flessa, H. 2005. Storage of organic carbon in aggregate and density fractions of silty soils under different types of land use. Geoderma. 128, 63-79.
Johns, W.D., Grim, R.E., Bradley, W.F. 1954. Quantitative estimation of clay minerals by diffraction methods. J. Sediment Petrol. 24, 242-251.

Kalbitz, K., Schwesig, D., Rethemeyer, J., Matzner, E. 2005. Stabilization of dissolved organic matter by sorption to the mineral soil. Soil Biol. Biochem. 37, 1319-1331.

Kemper, W.D., Rosenau, R.C. 1986. Aggregate stability and size distribution. In: Klute, A. (Ed.), Methods of Soil Analysis. Part I: Physical Analysis. SSSA. Madison, WI. pp: 425-442.

Kennedy, M.J., Pevear, D.R., Hill, R.J. 2002. Mineral surface control of organic carbon in black shale. Science. 295, 657-660.

Kerr, A. 2001. Carbon Sequestration. Department of forest ecology. 20pp.

Khormali, F., Ghorbani, R., Amoozadeh Omrani, R. 2005. Origin and distribution of clay minerals in different landforms of three selected watershed of eastern Golestan province. Research report. Gorgan University of Agricultural Sciences and Natural Resources. 78p. (In Persian).

Kimble, J.M., Heath, L.S., Birdsey, R.A., Lal, R. 2003. The Potential of U.S. Forest Soils to Sequester Carbon and Mitigate the Greenhouse Effect. CRC Press, New York.

Kittrick, J.A., Hope, E.W. 1963. A procedure for particle size separation of soils for X-ray diffraction analysis. Soil Science. 96, 312-325.

Lal, R., 2008. Carbon sequestration. Philos. Trans. R. Soc. B. $363,815-830$.

Lal, R., Kimble, J.M., Levine, E., Stewart, B.A. 1995. Soils and Global Change. Adv. Soil Sci. Published by CRC Press. 440 pp.

Martin, J.P., Haider, K. 1986. Influence of mineral colloids on turnover rates of soil organic carbon. In: Huang, P.M., Schnitzer, M._Eds., Interactions of Soil Minerals with Natural Organics and Mi- 
crobes. Soil Science Society of America Special Publication, vol. 17, Soil Sci. Soc. Am., Madison, WI. pp: 283-304.

Mbagwu, J.S.C., Piccolo, A. 1998. Water-dispersible clay in aggregates of forest and cultivated soils in southern Nigeria in relation to organic matter constituents. In: Bergstrom, L., Kirchman, H. (Eds.), Carbon and Nutrient Dynamics in Natural and Agricultural Ecosystems. CAB International, Wallingford, UK, pp: 71-83.

Mckeague, J.A., Day, J.H. 1966. Dithionite and oxalate extractable $\mathrm{Fe}$ and $\mathrm{Al}$ as aids in differentiating various classes of soil. Can . J. soil Sci. 46, 13-22.

Mehra, O.P., Jackson, M.L. 1960. Iron oxide removal from soils and clays by a dithionite citrate system with sodium bicarbonate. Clays and Clay Minerals. 7, 317-327.

Motamed, A. 1997. Quaternary. Tehran Univ. Press. 310 p. (In Persian).

Nelson, R.E. 1982. Carbonate and gypsum. In: Methods of Soil Analysis. Part II. Page, A. L. (Ed.). American Society of Agronomy, Madison, Wisconsin, USA.

Page, A.L., Miller, R.H., Keeney, D.R. 1982. Methods of Soil Analysis. Part 2. Chemical and Microbiological Properties, second ed. Agronomy Monographs, 9. ASA-SSA, MadisonParton, W.I., Schimel, W.J., Cole, D.S., Ojima, D.S., 1987. Analysis of factors controlling soil organic matter levels in Great Plains grasslands. Soil Sci. Soc. Am. J. 51 , 1173-1179.

Parton, W.J., Schimel, D.S., Cole, C.V., Ojima, D.S. 1987. Analysis of factors controlling soil organic matter levels in Great Plains grasslands. Soil Sci. Soc. Am. J. 51, 1173-1179.

Paustian, K., Six, J., Elliott, E.T., Hunt, H.W. 2000. Management options for reducing $\mathrm{CO} 2$ emissions from agricultural soils. Biogeochemistry. 48, 147163.
Rasmussen, P.E., Collins, H.P. 1991. Long-term impacts of tillage fertilizer, and crop residue on soil organic matter in temperate semiarid regions. Adv. Agron. 45, 93-134.

Rich, C.I., Obenshain, S.S. 1955. Chemical and clay mineral properties of a Red Yellow Padzolic soil derived from muscovite schist. Soil Sci. Am. Proc. 19, 334-39.

Schlesinger, W. H. 1999. Soil organic matter a source of atmospheric $\mathrm{CO}_{2} .28 \mathrm{p}$.

Shahriyari, A. 2009. Mineralogy and mineral phases preserving soil organic carbon in mollisols and mollisols like soils of Golestan province. M.Sc. thesis, Gorgan University of Agricultural Sciences and Natural Resources, 112 p. (In Persian).

Soil Survey Staff. 2010. Keys to Soil Taxonomy, 11th ed. U. S. Department of Agriculture. 346p.

Thomson, A.M., Cesar Izaurralde, R., Smith, S.J., Clarke, E.L. 2008. Integrated estimates of global terrestrial carbon sequestration. Global Environmental Change. 18, 192-203.

Tirol-Padre, A., Ladha, J.K. 2004. Assessing the reliability of permanganate-oxidizable carbon as an index of soil labile carbon. Soil Sci. Soc. Am. J. 68, 969-978.

Tron, M.S., Trumbore, S.E., Chadwick, O.A., Vitousek, P.M., Hendricks, D.M. 1997. Mineral control of soil organic carbon storage and turnover. Nature. 389, 170-173.

USDA-NRCS. 1999. Liming to improve soil quality in acid soils. Soil Quality- Agronomy Technical Note, No. 8.

Wiseman, C.L.S., Püttmann, W. 2005. Soil organic carbon and its sorptive preservation in central Germany. Eur. J. Soil Sci. 56, 65- 76.

Wiseman, C.L.S., Püttmann, W. 2006. Interaction between mineral phases in the preservation of soil organic matter. Geoderma. 134, 109-118. 